\title{
The social component of social-ecological research: moving from the periphery to the center
}

\author{
Alicia Castillo $^{1}$, Aída Atenea Bullen-Aguiar $^{1}$, Juan Luis Peña-Mondragón $^{1}$ and Norma Georgina Gutiérrez-Serrano $^{2}$
}

\begin{abstract}
Social-ecological research is an interdisciplinary endeavor. According to its research purposes, it includes biophysical aspects as well as political, economic, and cultural elements. However, to ensure that the analysis of social processes is effectively attended, it is recommended that biophysical scientists, ecologists in particular, explore the theoretical diversity within the social sciences. Drawing on our teaching experiences of more than a decade and our work as members of research teams that aim to move toward interdisciplinary work, we briefly explore four schools of thought in the social sciences explaining their philosophical and methodological dimensions, as well as the research methods they advocate. We propose that a deeper understanding of these issues will reinforce the dialogue between ecologists and social scientists and will enhance collaboration in social-ecological research projects. An invitation is also made to consider how interpretivism, constructivism, and critical theory can add value to social-ecological research when seeking to document and explain the perspectives of different stakeholders involved in the interaction between people and ecosystems. Related to this invitation we advocate that social-ecological science is essentially collaborative and needs to move toward knowledge coproduction emphasizing the relevance of communication and linkage strategies among diverse stakeholders in order to transit to sustainable socialecological systems. In order to illustrate some of our ideas, we present a case of social-ecological research related to the conservation of big predators in Mexico.
\end{abstract}

Key Words: barriers between social and ecological research; conflict human-carnivores; interdisciplinarity; multidisciplinarity; science and society; social science research traditions; transdisciplinarity

\section{INTRODUCTION}

The understanding of how ecological systems work or the analysis of the interaction of organisms with their physical environment (Begon et al. 1986), as well as explaining the processes that sustain life on Earth have been recognized as crucial for humanity (Ehrlich 1989, 1997). However, although ecological knowledge is essential, it is not enough to fully understand environmental problems and to construct ways to mitigate or solve them. The need to include the human dimension into ecological studies has been strongly advocated since the early 1990s (Lubchenco et al. 1991, Endter-Wada et al. 1998, Picket et al. 1999, Wear 1999, O'Neil 2001) and has led to the emergence of the concept of socialecological systems (SES), emphasizing how natural and human systems are integrated at different hierarchical scales in complex and dynamic ways that result in emergent properties (Berkes et al. 1998, 2003). The interaction between social factors and processes with ecosystem components, structures, and functions is at the core of the concept. Common frameworks that could allow integration of social and ecological elements in SES have been proposed such as the analysis of governance systems in relation to natural resources extracted from ecosystems, the role of direct users of such resources, the characteristics of the political system, policies, and markets as well as the ecosystems that are used (Ostrom 2009). Another example is the framework of Collins et al. (2011) where the examination of drivers influencing ecosystems and social systems through the recognition of "pulses" (sudden events) and "press" dynamics (extensive and unwelcome influences) is proposed to understand changes and the role of social factors such as markets and policies that impact the provision of ecosystem services (Collins et al. 2011). Although the use of the concept is expanding, the inclusion of social aspects in research has not been easy. One example is programs such as the existing networks of long-term ecological research (LTER). Groups of scholars have met and have published analyses strongly supporting the need to include the social dimension in these networks. They provide arguments for studying complex socialecological systems explaining that the human species cannot be treated as another organism because our species possesses features that provide us capacities of self-awareness, give meaning to objects and processes, as well as having the ability to learn quickly, reflect, and construct instruments that have exponentially increased the way in which we transform ecosystems at broad spatial and temporal scales (Westley et al. 2002, Redman et al. 2004). Some authors have proposed conceptual frameworks to transform the LTER networks into LTSER, advocating the study of human demography, economy, technology, institutions, culture, and information identifying integrative processes such as land use or mechanisms of production, consumption, and disposal of matter and energy (Redman et al. 2004). Another strategy for moving LTER into LTSER emphasizes governance and communication aspects as well as examining patterns and processes at different spatial and time scales, prioritizing historical factors that can explain present interactions between social groups and ecosystems (Haberl et al. 2006). Although these networks have not changed their names, they are making efforts: the International LTER has included the social dimension as a work group (http://www.ilter.network/) and the Mexican LTER network (created in 2004) now has socioecology as one of its eight thematic areas of research: society-nature interactions (Jardel et al. 2011).

${ }^{1}$ Instituto de Investigaciones en Ecosistemas y Sustentabilidad, Universidad Nacional Autónoma de México, ${ }^{2}$ Centro Regional de Estudios Multidisciplinarios. Universidad Nacional Autónoma de México 
On the other hand, throughout the last 15 years, some of the authors have participated in different projects that seek to transit toward interdisciplinary approaches where the majority of scientists have been ecologists. Also, we are seeing that postgraduate students educated in ecology have become more conscious and interested in how environmental problems such as biodiversity loss, land use changes, and pollution among many others are directly connected to social issues. To provide students enrolled in the Biological Science Postgraduate Program at the National Autonomous University of Mexico with an overview of the social sciences, the first author offers a course on the social dimensions of ecosystem management. The objective of this course is to revise the methodological foundations of the social sciences in the context of social-ecological studies. We agree with Jones and Merrit (1999) when they expressed their concern that most university programs related to environmental issues do not provide students with courses or other educational opportunities that acquaint them with the epistemological foundations and values at play in the disciplines they study. They also stress the need for students to develop critical thinking capacities in order to understand and analyze "the ways in which knowledge is produced and validated"(Jones and Merrit 1999:350). These skills are considered by the authors as prerequisites needed to integrate knowledge from different disciplines in order to achieve interdisciplinary work, essential when conducting SES research. We believe that the analysis of the interaction between social systems and ecosystems generates theoretical challenges; facing these would benefit the quality of SES research. Of particular interest is ensuring that the role of social research is better articulated within SES analysis (Spalding et al. 2017). In this way, and taking into account the lessons learned through the experiences mentioned above, the aim of this paper is to provide an overview of the complexity of the social component in SES research. It seems necessary for research on social-ecological systems to move from the periphery where it may be considered mere context, to the center where it should be considered as important as the ecological dimension. Historically the biophysical sciences have been central in the study of socialecological problems but at the root of the environmental crisis are human societies and their interaction with the natural world. The political, economic, and cultural components need to be better understood in order to solve the current challenges that threaten life on Earth. We examine what social scientists refer to as research traditions in order to help ecologists better understand their role when working in SES research. We also advocate that SES research is an applied science that needs to get involved in providing knowledge that can be used for mitigating and solving environmental problems. This is essential if SES analysis is to become better integrated and able to generate explanations that can play a relevant part in a wide range of decision-making processes that affect the present and future health of our unique local, regional, and global social-ecological systems. Although we emphasize ecologists as our main readership, we hope that the arguments presented here may benefit students and scholars of different backgrounds interested in social-ecological problems.

\section{KEY BARRIERS TO INTEGRATE SOCIAL AND ECOLOGICAL RESEARCH}

Barriers between the biophysical and social sciences play an important part in the lack of integration in SES approaches, particularly when it comes to problem identification and project design (Endter-Wada et al. 1998, Fox et al. 2006, Spangenberg 2011). According to Lélé and Norgaard (2005), there is a general belief that the natural sciences are quantitative and therefore rigorous and because the social sciences sometimes uses qualitative approaches are less rigorous. Recently, the interest in overcoming the barriers seems to be increasing within the ecological sciences as well as the social sciences. However, according to MacMynowsky (2007), when reviewing social science literature and published works in ecology pertaining to environmental issues, the publications do not show a connection and the literature and the sources of information do not cross. When working together, ecologists and social scientists acknowledge a "lack of mutual comprehension across disciplines" (Adams 2007:275), as well as differences, including disciplinary jargon, which results in misunderstandings, particularly regarding the conceptual ideas behind the terminology used. For example, the concept of competition for ecologists denotes exclusion between species whereas for economists it may refer to rivalry between firms (Wear 1999). Authors such as Fox et al. (2006) stress the need to construct a common language, and Spangenberg (2011) proposes an SES dictionary of clearly defined terms. However, we argue that this may not be fully possible and certainly is not enough. What may be needed is for scientists to learn to convey the ideas behind concepts (Adams 2007), to learn to explain, listen, and to reflect upon what different disciplines and actors have to say about SES problems. In this way, bridges can be constructed.

The challenge, for biophysical and social scientists alike, is to venture into "the other" field of scientific enquiry (Newing 2011). Social scientists need to learn more about ecology and evolution: it is common, for example, to see a general lack of understanding that life on our planet began thousands of millions of years ago and has gone (and is still going) through evolutionary driving processes. Likewise, ecologists would benefit from acquiring a basic understanding of how the social sciences work. A difficulty is that although biophysical scientists may have a genuine interest in better understanding SES, they commonly argue that they do not have the time for teamwork (Naiman 1999, Balvanera et al. 2017). This includes getting involved in group processes of sharing concepts, frameworks, and questions (Picket et al. 1999), as well as learning about how the social sciences function and how to work with nonscientific stakeholders to produce SES research that has an impact on real world problems. Because SES research is inter- and transdisciplinary, efforts must be made to revise both the ontological (regarding the conception of reality) and epistemological (our conception of knowledge) dimensions of different social science research approaches, particularly because these differences have significant implications for methodological design and in how the different research methods are used.

In some academic circles (such as ours), the social sciences continue to be perceived as second class sciences, and are underestimated in their achievements; titles such as Making Social Sciences More Scientific: The Need for Predictive Models (2008) by Rein Taagepera exemplify a sense of inadequacy shared by some. This viewpoint has long historical roots that we will not discuss here, but will be illustrated by a debate that took place in 1961 between two philosophers known for their study of science: Karl Popper (1902-1994) and Theodor Adorno (1903-1969). In 
this exchange, we can observe the divide that exists between two distinct views of science, the first associated with the biophysical disciplines, the Positivists. The second represents a particular school of social thought commonly known as Critical Theory (Adorno et al. 1976). In that debate, Karl Popper presents 27 theses in which he promotes an objective method for the social sciences as used by the biophysical scientists. This particular form of social science seeks to find regularities and functionality within systems and generate categories through hypothetical-deductive methods. Popper considered that the logic of the social sciences, like its natural counterpart, should begin by identifying problems arising from contradictions between what we know and how things are, and then he recommends the production of probable solutions that would be tested using experimental methods to disprove the hypothesis, much like the natural sciences work. Furthermore, he implies that the social sciences follow an absurd "pseudo-scientific method" accepting everything that is relative, as if it was dogma (Adorno et. al. 1976). In his 14th thesis, Popper calls topics such as "human welfare," "national defense," "industrial expansion," or the "acquisition of personal wealth" as "extra scientific problems" that influence scientific research and proposes they be differentiated from those issues that are concerned with the search for truth and pure scientific interest (Adorno et. al. 1976:6). He also makes the case that scientific values such as the richness of the results, the explanatory capacity, its simplicity, and its preciseness, should guide research. The search for truth would determine if the problem investigated was scientific or not. For most social scientists, these aspects cannot be taken as rigid guidelines because there are subjective elements in social phenomena. For this reason, the primary intention is to comprehend the experiences of social actors. Adorno's (1976) response to Popper's judgments, begin by emphasizing the difference between analyzing objects and subjects (humans), reminding us that social phenomena are contradictory in nature, and require a different investigative approach. Studying subjects, "rational" agents, relationships, and nonmaterial phenomena in constant flux cannot use the same tools used for objects (Adorno et. al. 1976). Thus promoting a method used by biophysical scientists would fail from the start, because it would be unable to account for the complex and diverse forms of social organization. An unfathomless divide becomes obvious when reading Popper's and Adorno's debate.

Furthermore, there is a real methodological predicament that hampers the ability to integrate social and ecological phenomena. The scientific study of the interactions of humans with the natural world initiated in the 19th century, conducted mainly by ethnologists (Clements 1998), these challenges were accelerated by the burgeoning environmental sciences that began taking shape in the later part of the last century when ecological and social elements were brought together by other disciplines. Reflecting on the similarities and differences between ecosystems and social systems, Westley et al. (2002:105) argue that "temporal/spatial dimensions key to ecosystem dynamics contrast with the temporal/spatial/symbolic dimensions key to social systems," in that the symbolic dimension shapes the "structure of signification" (Westley et.al. 2002:105) and in turn is influenced by it, allowing "human systems to divorce themselves to some degree from space and time" (Westley et.al. 2002:108-109), thus requiring different tools for its study.
In sum, based on the arguments selected from the Popper-Adorno debate, we can identify two basic challenges for social-ecological research: first, separating the social and ecological aspects of research and later integrating them will not provide adequate information of the relations that exist among them. This represents a problem for multidisciplinary research teams more so than interdisciplinary and transdisciplinary projects because in the former, researchers from various disciplines carry out their work separately following their own epistemological stands and methodologies and only bring together their results without carrying out an integrated analysis that can override the fundamental differences in scales and the information generated (García 2011). For this reason, biophysical topics (geology, vegetation, fauna, ecological dynamics, etc.) and social aspects such as population demography, economy, or cultural aspects are commonly presented as separated chapters in reports. In the later (interdisciplinary and transdisciplinary), the research questions, the methods, the analysis, and the results are all integrated from the beginning, making both the ecological and the social components essential parts of the project. A second challenge arises from the fact that, for integration to occur, it is necessary to develop the capacity to analyze two different complex phenomena, one of which uses predominantly a hypotheticaldeductive method and the other that tends to use inductive or interpretative approaches, among a plethora of different schools of thought that could be used to answer questions in SES research. We explain some of these approaches. Understanding human societies (contrary to the biophysical world) requires mechanisms to understand meaning of social phenomena including issues related to cognitive, linguistic, and emotional aspects. Because we researchers are humans, knowledge cannot be separated from the knower because her/his work is rooted on her/his mental designations of the world (Lincoln and Guba 2000).

\section{THE COMPLEXITY OF THE SOCIAL DIMENSION}

As has been mentioned, within the field of environmental or social-ecological research, far more researchers are trained in the biophysical rather than the social sciences (Brondizio et al. 2016), and very few understand both social and ecological research approaches. Although it is not necessary for every ecologist interested in working within a social-ecological approach to become a social science researcher, it is nonetheless important that they acquire a basic understanding of certain assumptions within the social sciences regarding the nature of the world around us and the ways in which we can understand it (Newing 2011). The opposite is also true; a deeper understanding of essential ecological concepts by social scientists will help in the construction of research strategies within inter- and transdisciplinary research teams.

For the purpose of this paper, it is useful to provide some general ideas about four different traditions that are representative of the diversity that exits in the social sciences. Traditions refer to the "system of ideas and practices organized as rules and rituals of symbolic nature that are tacit or explicit and are meant to inculcate certain values and norms produced in determined groups or in societies" (Hobsbawn 1983, as cited in Tarrés 2008:35), and we speak of scientific communities and their particular epistemological systems. The idea of tradition is similar to that of paradigm, which is conceived as a vision about the world that is shared and accepted by particular groups of scholars, thus 
determining how scientists formulate and investigate a problem (Robottom and Hart 1993). This notion of paradigm, initially formulated by Thomas Kuhn (1970) helps explain how knowledge is produced and shared, as well as how the rules of the scientific community, regarding conceptual and methodological elements, are accepted to constitute the norm. When new explanations are presented and they are accepted by the scientific community who modifies previous ideas, there is a shift in the paradigm and a scientific revolution occurs (Khun 1970). Here we emphasize that the way in which we construct a scientific project is influenced by the scientific tradition or paradigm in which we position ourselves. This defines us not only in the research methods we choose (which may be shared among traditions) but more importantly in how we design research instruments in particular, i.e., how we word the questions either in an interview or a survey. In addition, this shapes the results we obtain as well as the interpretations that we generate about social phenomena which we will later share with our peers and the rest of society.

However, researchers should not think of traditions as entrenched cages but more like philosophical lenses through which a variety of perspectives offer different ways to conduct research (Cantrell 1993). Some of the main traditions that we acknowledge as relevant and useful for SES research are: positivism, constructivism, interpretivism, and critical theory (Cantrell 1993, Denzin and Lincoln 2000, Newing 2011).

Three of these are represented by the three founding fathers of classical sociology: Emile Durkheim (positivism), Max Weber (interpretivism) and Karl Marx (critical theory). Constructivism is more closely associated to developmental psychology and pedagogy and Jean Piaget is perhaps its most famous figure. Each of these traditions can be analyzed in terms of the ontological precepts, their epistemological basis, and the methodological approaches (Lincoln and Guba 2000).

By ontology we refer to the nature of the phenomena, be it an "objective" reality or a social construct. The epistemological discussion will pertain to the process of inquiry and the relation that it is established between the researcher and the object or subjects of study. How the study will be conducted, and what methods will be used to obtain, analyze, and interpret the information are methodological aspects. It should be stressed that some authors identify two contrasting perspectives that are assumed to be research models: quantitative versus qualitative research (Newing 2011). This may cause confusion because the difference between them is not about the type of data they use (quantitative or qualitative) but the ways in which reality is studied. In all traditions, both quantitative and qualitative data can be used, although some schools prefer one perspective over the other. Positivism is commonly taken as quantitative whereas constructivism, interpretivism, and critical theory are placed under the qualitative research umbrella. Table 1 shows the essential differences between these four ways of conducting social research briefly explaining issues of ontology, epistemology, the use of methods to gather social data, and the role of researchers.

From the positivist perspective, reality can be observed and analyzed objectively, that is, without the intrusion of the views of the observer or the researcher who collects data about a particular social phenomenon. Phenomena can be fragmented into pieces or variables, which can then be quantified to produce results that reveal causal relations (Newing 2011). These ideas are at the core of the natural sciences and for positivists in the social sciences, the scientific method can be used as such (Robottom and Hart 1993, Lincoln and Guba 2000). The label positivism was actually coined and made famous by Auguste Comte (1798-1857), a philosopher and author of the Course on Positive Philosophy (1830), who believed that social phenomena should be studied much like the biophysical world. Adhering to this perspective, Emile Durkheim (1858-1917), one of the founders of the field of sociology, believed in the importance of observation, empirical investigation, and the use of hypothetical-deductive logic. He studied social phenomena as social facts that exist as part of a "real" objective reality, independent of the observer. In this context, sociology tries to discover the regularity that exists in the general relationships that occur within institutions or particular practices (Durkheim 2001). This position did not prevent him from combining qualitative and quantitative data as he explains in The Rules of the Sociological Method (2001).

Based on their scientific training, it is common that when biophysical scientists incorporate a social dimension into their research projects, the research method they most often use is quantitative surveys (Adams 2007, Drury et al. 2011). Quantitative surveys are not problematic in themselves: it is the way they are used that can sometimes be problematic. With a positivist approach, the objective is to gather as much quantitative data as possible. Frequently these surveys are designed with closeended questions that offer respondents a range of options to choose from. These options commonly represent what the researcher thinks are the possible answers and, allow little or no space for respondents to express their own ideas. Drury et al. (2011) argue that it is only when a researcher has prior knowledge and a deep understanding about the people and communities being studied, that surveys can collect useful information from which valid conclusions and explanations can be drawn. Surveys are also a very good way to collect socioeconomic data and other specific data needed for an investigation.

In the field of anthropology a recognized author, Clifford Geertz (1926-2006) opted for qualitative data. Again the diversity of authors illustrates the richness of the field and the subtle variations that will influence the quality of research as it is implemented. Nevertheless, under the interpretivism tradition, the objects of study are the subjects that create meaning and thus they may not be reduced to the study of social facts, but should focus on trying to comprehend the subjective meanings of their social action (Patton 2002). Unlike positivism, reality is dependent on the individuals whose thoughts and actions must be interpreted in order to comprehend its meaning (Tarrés 2008).

Closely related to interpretivism, is constructivism, whose main authors are considered by some as interpretativists, but in this paper we will differentiate them because of its epistemological stands as well as the diversity of theoretical and methodological positions. Martín Retamozo (2012) identifies at least four types of constructivism; some, like Jean Piaget (1896-1980) accept the existence of an external reality, and others like Heinz Von Forester (1911-2002) believe that language constructs reality (Retamozo 2012). However, what they all have in common is the question of how knowledge is produced by the individual. In this sense, they will seek to comprehend their observations and perceptions 
Table 1. Distinctive characteristics of four research traditions in the social sciences.

\begin{tabular}{|c|c|c|c|c|}
\hline Tradition & Positivism & Constructivism & Interpretivism & Critical Theory \\
\hline Purpose & $\begin{array}{l}\text { Find laws that can explain } \\
\text { and predict phenomena } \\
\text { (Newing 2011). }\end{array}$ & $\begin{array}{l}\text { Attempt to understand how } \\
\text { humans know and produce } \\
\text { scientific knowledge (García } \\
\text { 2006). }\end{array}$ & $\begin{array}{l}\text { Explain phenomena } \\
\text { according to the meanings } \\
\text { subjects give to them } \\
\text { (Cantrell 1993). } \\
\text { Pursues significance and } \\
\text { meaning (Geertz 1973). }\end{array}$ & $\begin{array}{l}\text { Raise consciousness for social } \\
\text { change (Lincoln and Guba } \\
\text { 2000). }\end{array}$ \\
\hline Ontology (nature of reality) & $\begin{array}{l}\text { A unique reality does indeed } \\
\text { exist and can be fragmented } \\
\text { for analysis } \\
\text { (Cantrell 1993, Robottom } \\
\text { and Hart 1993). } \\
\text { Reality is real and can be } \\
\text { apprehendable (Lincoln and } \\
\text { Guba 2000). } \\
\text { Reality is externally objective } \\
\text { (Adorno et al. 1976). } \\
\text { There is a dichotomy } \\
\text { between the subject and the } \\
\text { object (Adorno et al. 1976). }\end{array}$ & $\begin{array}{l}\text { There are differences among } \\
\text { constructivists. } \\
\text { For social constructivists, } \\
\text { reality is a cultural construct; } \\
\text { for others like psychogenetic } \\
\text { constructivists, reality is an } \\
\text { external physical } \\
\text { phenomena. For } \\
\text { constructivists that belong to } \\
\text { the cognitive development } \\
\text { school and for } \\
\text { postmodernists, reality } \\
\text { depends on language } \\
\text { (Retamozo 2012). }\end{array}$ & $\begin{array}{l}\text { Constructed socially; } \\
\text { multiple visions of reality } \\
\text { coexist (Cantrell 1993, } \\
\text { Robottom and Hart 1993, } \\
\text { Lincoln and Guba 2000). }\end{array}$ & $\begin{array}{l}\text { The object is constructed } \\
\text { historically as a result of } \\
\text { social praxis and thus } \\
\text { responsible for it (Adorno et } \\
\text { al. 1976). } \\
\text { Reality is shaped by social, } \\
\text { political, cultural, economic, } \\
\text { ethnic, and gender values } \\
\text { crystallized through time } \\
\text { (Lincoln and Guba 2000). } \\
\text { Social action is the object of } \\
\text { study } \\
\text { (Cantrell 1993, Robottom and } \\
\text { Hart 1993). } \\
\text { Reality exists at two levels: the } \\
\text { level of the subject and the } \\
\text { structure. Both are part of an } \\
\text { integrated whole that cannot } \\
\text { be broken nor divided for its } \\
\text { study (Horkheimer 2003). }\end{array}$ \\
\hline $\begin{array}{l}\text { Epistemology (nature of } \\
\text { knowledge) }\end{array}$ & $\begin{array}{l}\text { Researchers can prove the } \\
\text { causes of phenomena } \\
\text { (Newing 2011). } \\
\text { Verification of hypothesis } \\
\text { produces facts and laws } \\
\text { (Lincoln and Guba 2000). } \\
\text { Hypothetical-deductive } \\
\text { approach (Adorno et al. } \\
\text { 1976). }\end{array}$ & $\begin{array}{l}\text { Constructivism asks what } \\
\text { knowledge is and how it is } \\
\text { produced (García 2006). }\end{array}$ & $\begin{array}{l}\text { Understanding phenomena } \\
\text { depends upon the } \\
\text { researchers' interpretation of } \\
\text { the subjects' notions and } \\
\text { experiences (Cantrell 1993, } \\
\text { Robottom and Hart 1993). }\end{array}$ & $\begin{array}{l}\text { Understanding based on the } \\
\text { socioeconomic and cultural } \\
\text { situation. } \\
\text { Emphasis is placed on the } \\
\text { critical analysis of the } \\
\text { situation, including the } \\
\text { historical context } \\
\text { (Cantrell 1993, Robottom and } \\
\text { Hart 1993, Horkheimer 2003). }\end{array}$ \\
\hline Methodology & $\begin{array}{l}\text { Experimental, manipulative, } \\
\text { hypothesis verification } \\
\text { (Lincoln and Guba 2000). }\end{array}$ & $\begin{array}{l}\text { Experimental, manipulative } \\
\text { but also attempts to interpret } \\
\text { cognitive processes } \\
\text { (Retamozo 2012). }\end{array}$ & $\begin{array}{l}\text { Flexible design that allows } \\
\text { the researcher to modify the } \\
\text { questions and the data } \\
\text { collection methods } \\
\text { throughout the investigation } \\
\text { according to the findings } \\
\text { being encountered (Cantrell } \\
\text { 1993, Janesick 2000). }\end{array}$ & $\begin{array}{l}\text { Historical analysis that studies } \\
\text { social economic relations, as } \\
\text { well as other nonexperimental } \\
\text { methods (Lincoln and Guba } \\
\text { 2000). } \\
\text { Participatory action research } \\
\text { (Hernández 2010). }\end{array}$ \\
\hline Data collection techniques & $\begin{array}{l}\text { Questionnaire-based surveys } \\
\text { are the main method of } \\
\text { obtaining quantitative data } \\
\text { to be analyzed through } \\
\text { statistical tests } \\
\text { (Cantrell 1993, Robottom } \\
\text { and Hart 1993, Drury et al. } \\
\text { 2011). }\end{array}$ & $\begin{array}{l}\text { Participant observation and } \\
\text { interviews. } \\
\text { Discourse analysis (van Dijk } \\
\text { 2016). }\end{array}$ & $\begin{array}{l}\text { Ethnography (Geertz 1973). } \\
\text { Interviews, participant } \\
\text { observation, and dialogue } \\
\text { with subjects. Texts are } \\
\text { analyzed through coding } \\
\text { processes } \\
\text { (Cantrell 1993, Robottom } \\
\text { and Hart 1993). }\end{array}$ & $\begin{array}{l}\text { Participant observation. } \\
\text { Interviews, historical archival } \\
\text { documentation, workshops, } \\
\text { sociodrama, social mapping, } \\
\text { problem trees (Hernández } \\
\text { 2010). }\end{array}$ \\
\hline Role of researcher & $\begin{array}{l}\text { Independent of the object } \\
\text { (Cantrell 1993, Robottom } \\
\text { and Hart 1993). }\end{array}$ & $\begin{array}{l}\text { Dependent on the subjects } \\
\text { (van Dijk 2016). }\end{array}$ & $\begin{array}{l}\text { Seeks dialogue with subjects } \\
\text { (Cantrell 1993, Robottom } \\
\text { and Hart 1993). }\end{array}$ & $\begin{array}{l}\text { Strong commitment with } \\
\text { social actors } \\
\text { (Cantrell 1993, Robottom and } \\
\text { Hart 1993). }\end{array}$ \\
\hline
\end{tabular}


(Retamozo 2012). For the aforementioned reasons, qualitative methods are the preferred choice.

Lastly, critical theory much like constructivism, is far too complex to be described as an integrated epistemological tradition; it has been historically identified with the famous Frankfurt School. Spanning several generations of thinkers and integrating a variety of philosophical perspectives, they share their interests in nonorthodox critical Marxist theory. Max Horkheimer (18951973 ) in his discussion of what constitutes a theory proposes that there is a fundamental difference between facts and concepts, and that the latter are mediated by social praxis (Horkheimer 2003). In this sense human activity will become the object of analysis. Moreover, because human contradictions have ethical and political dimensions, critical theory aligns itself toward the emancipation of those who are oppressed by any form of despotic authoritative regime; its goal is to end social injustice (Horkheimer 2003). Thus, it not only generates theory but also promotes concrete actions based on a strict theoretical reflection of society. Because emancipation is the central theme, a methodology that includes participation was born in Latin America in the late 1960s and would later be known as participatory action research. The main scholars were Paulo Freire (1921-1997) and Orlando Fals-Borda (1925-2008). This form of inquiry within the tradition of qualitative research modes is an approach in which the researchers collaborate with local individuals and their communities in order to generate integrated research questions that are aimed at transforming some aspect of the reality under study (Anderson and Montero-Sieburth 1998). Apart from collecting data, participatory methods help to identify people's specific needs and insights into their ways of understanding the world and the activities they can undertake based on their perspectives, needs, and motives. Through such methods, scientists can better accomplish their social responsibility objectives.

Methodologically speaking, practitioners of qualitative approaches that include constructivism, interpretivism, critical theory, and participatory research prefer methods such as interviews with open-ended questions. They prefer to talk to respondents (Patton 2002), either as individuals or within focus groups (Newing 2011), and to listen and document their views and perceptions about the issues under study. Only through letting people express their ideas, needs, motivations, and problems, is it possible to understand the social dimensions of SES problems. Interviews with clear topics addressing an issue (known as semistructured interviews, see Newing 2011), are a popular research method (Fontana and Frey 2000, Drury et al. 2011). Participant observation is another core method, which allows for the collection of data through observations that a researcher makes when participating in the daily activities of the subjects involved in the phenomena under analysis (Yin 2016).

The data obtained through the variety of qualitative methods are mostly texts that can be analyzed through the construction of categories or codes through an inductive process. That is, the researcher acts as the recording instrument letting the data speak through the categories that emerge from field notes, interviews transcripts, and documents (Strauss 1995, Janesick 2000). They generate narratives, which construct descriptions of the phenomena under study. These narratives are essential if a SES problem is to be properly understood and if decision-making processes regarding human livelihoods and ecosystem maintenance are to be properly informed (Waltner-Toews et al. 2003). Figure 1 illustrates the research traditions revised in the context of social-ecological systems.

Fig. 1. The analysis of social-ecological systems. On the left side of the figure we find the research approaches used to study biodiversity and ecosystems. Inside the yellow box are the social science traditions discussed in this paper. Surrounding it, we illustrate that people benefit from nature (or ecosystem services) and that human societies discharge waste into nature.

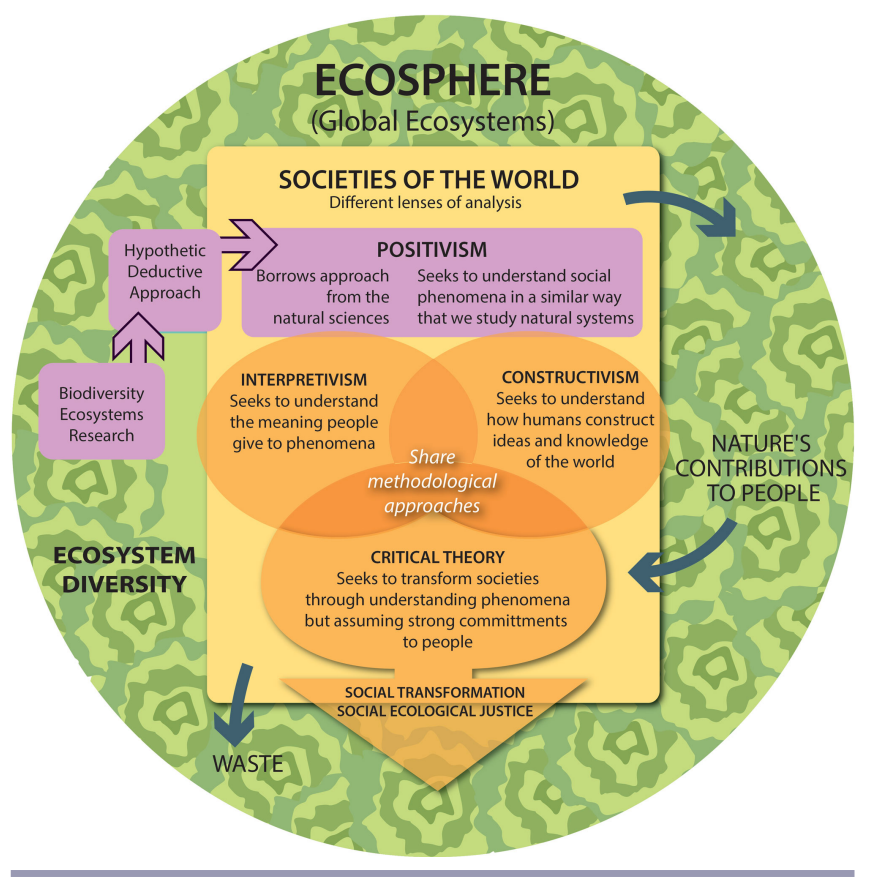

Although traditions are based on different assumptions, they are not irreconcilable (Lincoln and Guba 2000). Depending upon the research questions, these may show confluences that will lead to comprehensive results and explanations. Extreme loyalty to a school of thought may delay or hinder the exploration of novel ideas that may work better for particular situations (Lélé and Norgaard 2005). However, a vigorous debate and self-reflexivity within the social sciences, beginning as far back as the 1970s, has led to the predominance of qualitative research that in itself crosses multiple disciplines as well as traditions, and continually examines and revises its own tensions and hesitations (Denzin and Lincoln 2000). The qualitative research traditions share the notion that reality is socially constructed because each individual sees the world in different ways depending on her/his own cultural background, experiences, and interactions with other human subjects (Berger and Luckman 1991, O'Brien and Kollock 2001). It stresses the importance of understanding "how the social experience is created and given meaning" culturally (Denzin and Lincoln 2000:8), as well as exploring domination (power interactions among people), legitimation (the norms that guide social life), and as mentioned above, the human capacity to give meaning (through language, symbols, and communication), all of which constitute the heart of social systems (Westley et al. 2002). 
It is also important to emphasize that for a scientist to conduct a project that includes a social dimension (in other words all SES analyses), they must ensure that ethical issues are addressed. Researchers should obtain permission from the pertinent local authorities to conduct research, and informed consent must be obtained from all research participants. Establishing trust with research participants and, indeed, with the wider community, is essential, and respect is expected from scientists at all times (Yin 2016). We emphasize these aspects because they are aspects not often included in the curricula of biophysical scientists (although at present some educational programs include bioethics in their curricula) and it is essential to know how to behave when conducting social research. It is also important that researchers establish guidelines and commitments with the communities where they work, regarding how they will use the data generated. This includes, but is not limited to how they will share the results of the study, in a language and format that is accessible to the community. This is a task that researchers should be able and willing to carry out (Castillo et al. 2018).

Until now we have presented a very simple overview of four traditions that represent different outlooks in the social sciences, but rather than continue to extend the discussion on each tradition, the differences, and their similarities, we invite the readers to select the tradition that best matches their own interests and explore the possibility of including it in their projects. A suggestion for integration is proposed below and an example is later given of a case study of carnivores and rural communities in Mexico.

\section{THE INTERDISCIPLINARY CHALLENGE}

The study of environmental problems in the mid-20th century, posed the problem of the fragmentation of knowledge. At the same time, the General System Theory: Foundations, Development, Applications (1969) by Ludwig von Bertalanffy (1901-1972), influenced the discussion among disciplines regarding the study of complex environmental problems. In this context, socialecological research became an interdisciplinary challenge because it attempts to bring together two distinct fields of study and various disciplines in response to the environmental crisis. It is not surprising that, since nearly seven decades ago (MacMynowsky 2007) the exchange and integration of knowledge between disciplines and traditions has been recognized as indispensable in order to understand and take action to solve society's problems. In relation to this, authors such as Funtowicz and Ravetz $(1993,2003)$ argue that most of these problems are complex and have a high degree of uncertainty, they include a variety of stakeholders with different interests and values (many times in dispute), and they require urgent answers, which cannot be addressed by the conventional approaches as used in disciplinary research. They acknowledge the value and contributions of disciplinary research, which they refer to as normal science, but they propose a new approach called postnormal science that uses a different methodology. The main idea is that from the moment a problem is identified, it needs to be examined not only by scientists but also by the whole range of stakeholders involved, forming what they call extended peer communities. These actors provide knowledge and participate in its construction. Many of those affected by the problems can participate in the assessment of research findings and possible solutions. Other authors such as Gibbons et al. (1994) share a similar view referred to as Mode 1 of knowledge production to what is conducted in disciplinary science, and Mode 2, the research that is inter- and transdisciplinary where the needs and understanding of stakeholders are considered under a framework of collaboration and continuous negotiations. Both approaches aim to contribute to inform policy formulation or the construction of strategies that help mitigate or solve real-life problems.

Nevertheless, there are calls from scholars and those interested in the interdisciplinary analysis of human interaction with ecosystems to examine what interdisciplinary research means, which obstacles exist, and how issues of power and human values come into play (MacMynowsky 2007). Nissani (1997:203) begins by defining a discipline as "any comparatively self-contained and isolated domain of human experiences which possesses its own community of experts." For this author, interdiscipline brings together at least two or more components of different disciplines. Authors such as Adams (2007) think that interdisciplinarity is a quality that may be cultivated by individuals. Both individuals and research teams need to be self-reflective about their choices regarding conceptual referents and be willing to learn about other disciplines (Lélé and Norgaard 2005) and to enrich research by bringing "fresh insights and methodologies" from various disciplines for innovation (Nissani 1997:205). Similarly, García (2011) considers that what distinguishes interdisciplinary teams from multidisciplinary work groups is how the problem is constructed and how the phenomena is studied. Multidisciplinary approaches divide the problem in order to study it from different disciplinary angles, while interdisciplinary studies work with an integrated problem from the beginning (García 2011).

Reaching beyond interdisciplinarity is transdisciplinarity where relationships are formed between, through, and beyond the disciplines (Nicolescu 2012). Some recommend that interdisciplinary projects should be conducted through team work. There is an urgent need for truly collaborative and integrative research in SES, this meaning that scientists and their institutions accept the challenge and responsibility to cross the bridges from their own particular disciplines to those on the other side that are needed to understand and to construct explanations regarding the critical and complex problems our planet is facing at present (Brondizio et al. 2016). Collaborative work is therefore essential although it is not easy to carry out; there is a need to transit from a rhetorical discourse to the formulation and implementation of successful interdisciplinary projects. Members of these research teams should possess an interdisciplinary outlook that will facilitate the interaction with others; otherwise experts of different disciplinary fields will form a multidisciplinary team at best. By outlook we mean the capacity "to internalize a set of practices and understandings about how valid knowledge is created" in different disciplines (Schoenberger 2001:367). Being open to different "epistemological commitments" beyond our own discipline is necessary for interdisciplinary research and thus social-ecological investigation. Obviously, this is easier said than done because "disciplinary cultures and their associated epistemological commitments shape our ways of thinking about the material and the social world and how we understand ourselves and our possibilities for action in that world" and thus are limited by our beliefs more than we would like to accept (Schoenberger 2001:370). In contrast, multidisciplinary researchers could work 
independently and contribute to a project with minimum interaction.

Even if epistemological, ontological, and disciplinary culture were not enough challenges for interdisciplinary social-ecological work, the fact that the nature of the phenomena under study is so much different poses another problem to be resolved. In order to address this, a possible coupling of the systems would move social systems to the center allowing the examination of its interaction with ecosystems (see Fig. 1). An interdisciplinary approach would benefit from an understanding of the ontological basis, epistemological stands, and methodological strategies preferred by the different social science schools, while also promoting an intense dialogue (Freire 1998) with scientists of different disciplines and stakeholders of very different backgrounds.

\section{SES RESEARCH INVOLVES COLLABORATION AND ACTION}

As emphasized earlier, SES research should aim not only at understanding phenomena but also to produce an impact and help the transformations needed to transit to more sustainable SES (Kates et al. 2001, Kates 2011). Some social research traditions such as critical theory are based on the need for scientists to get involved in such transformations recognizing the need to strongly change humans' interactions that impede peoples' access to equality, justice, and self-determination (Lincoln and Guba 2000). Other traditions such as positivism, view political action as a form of contamination of research putting at stake its neutrality (Lincoln and Guba 2000). However, interdisciplinary work such as SES research, is based not only on identifying problems but also in providing ways for mitigating or solving them. With the environmental crisis getting worse at all scales (notwithstanding the multiplication of fruitful local efforts) urgent calls are being raised by the scientific community to get involved in working with different stakeholders to construct strategies for harmonizing societies interactions with ecosystems. Transdisciplinary work, where scientific enquiry is based on problems that require the involvement of a great diversity of stakeholders (Spangenberg 2011) is getting more support as SES problems at all spatial scales become critical.

A good way to move toward collaborative SES research is to view the scientific practice not only in charge of knowledge generation, but to locate it within a framework that connects knowledge construction with its communication and use (Beal et al. 1986, Castillo et al. 2005, 2018). It is necessary to view these processes as forming part of the same system where scientists, as well as a variety of actual and potential stakeholders work together in close communication (Walters 1998), establishing a clear pathway from problem identification and the establishment of research questions and agendas. The idea is to transit into knowledge coproduction schemes (Wehrens 2014, Schuttenberg and Guth 2015) leading to the use of outcomes. Scientists have much to share with society and in the 21 st century it is of great importance to be involved in the construction of SES management strategies based on interdisciplinary and transdisciplinary research efforts (see Fig. 2). Transdisciplinary work is essentially problem driven and it requires scientists in collaborative teams to learn to work with a variety of disciplines but importantly with actors from outside academia identifying and describing the issue, generating knowledge, and integrating it so it serves to implement evidencebased action programs and strategies that enhance the decisionmaking capacities of the involved stakeholders (Lang et al. 2012). We present the following case study as an example of SES research aimed at contributing to the conservation of predators. Basic biological and ecological knowledge about the species is essential and an interpretive social science approach favored the comprehension of the conflict with human settlements in rural Mexico. Communication and educational activities have accompanied the research in order to generate changes in the way people perceive these animals and their own livestock management practices.

Fig. 2. Knowledge generation, its exchange, integration, and utilization are integrated in the same system that contributes to inter- and transdisciplinary social-ecological systems (SES) research. The arrows connect the different aspects highlighted in the aforementioned processes. The actors involved are researchers (easily recognized on the left side as responsible for SES research) but also nonacademic stakeholders participating in inter- and transdisciplinary work. Emphasis is made on the construction of research agendas with diverse actors who bring knowledge, perspectives, and needs. It is through processes of exchange and integration that knowledge coproduction can occur and knowledge used, either to change actors' ways of thinking or their ways of doing things (both scientists and other stakeholders).

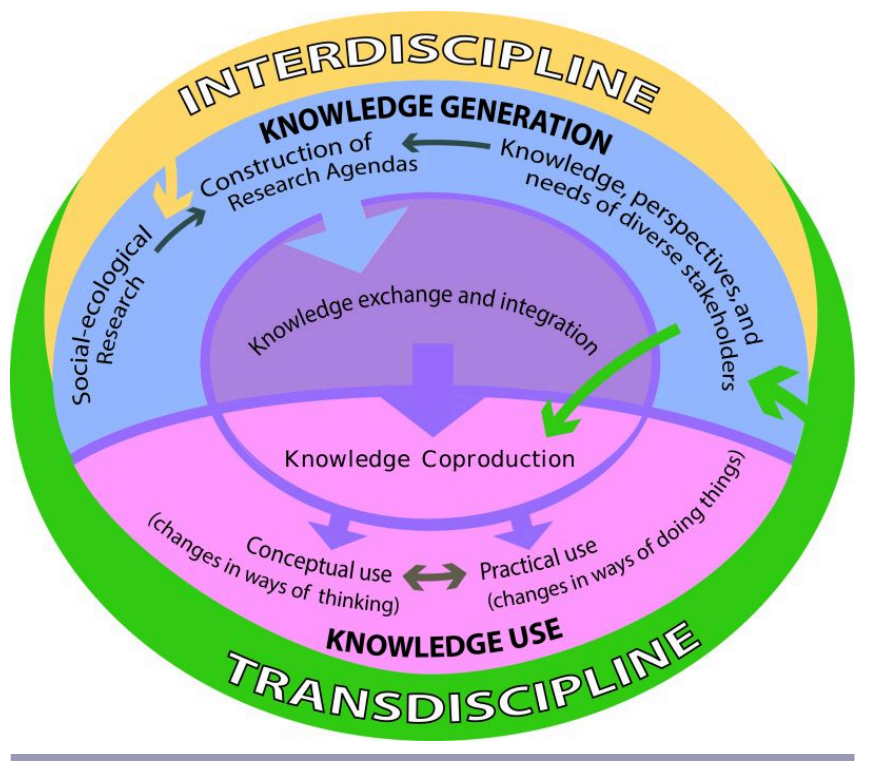

\section{MITIGATING THE CONFLICT BETWEEN CARNIVORES AND HUMAN COMMUNITIES THROUGH A SES APPROACH}

Historically, the study of big predators has focused on ecological investigations such as diet, distribution, and habitat use. The main conservation instrument for their protection in Mexico has been the decree of Natural Protected Areas. However, because carnivores need large territories and an abundance of prey, current protected areas are insufficient to secure their long-term maintenance. Because of pressures on their habitats, these animals 
are forced to live and roam closer and closer to human settlements, frequently damaging crops and livestock. In the southern part of Nuevo León in northeast Mexico, rural communities have serious problems with carnivores such as jaguars (Panthera onca), cougars (Puma concolor), and black bears (Ursus americanus) preying on their domestic animals. People mainly deal with the problem by killing medium and large sized animals. In order to understand and address this situation, we initiated a social-ecological project in 2009 that includes analyses of ecological aspects of the species, the socioeconomic and cultural dimensions of the conflict, as well as outreach activities aimed at effecting changes in the way people perceive the species, their attitudes toward carnivores and their livestock management.

Initially, several field visits to rural communities were conducted in order to get access to the people and to gather information through informal talks about the ideas people had about the predators. These visits helped to build trust among the people and the research team. This process was slow to come because predator species are under severe threat and under legal protection. Therefore, people do not like to talk or give information about them. Explaining the reasons for conducting the research took more than a year, but eventually the communities agreed to participate. Another strategy that was used was to approach local organizations through attending the annual meetings of the Livestock Associations comprising 200 members in Aramberri and 600 in General Zaragoza, two municipalities in the area (see Fig. 3). After explaining the aims of the study, which included evaluating the economic losses caused by predation and pledging to return the results to the locals, people were interested and accepted to participate. The research team was given permission to work and received full support. After obtaining people's consent, a survey (with closed and opened-ended questions) of 80 people in 60 rural communities showed that between 1992 and 2010 livestock losses accounted for almost US\$135,000. The animals that caused the most damage were black bears, followed by jaguars, cougars, coyotes (Canis latrans), bobcats (Lynx rufus), and grey fox (Urocyon cinereoargentus; Peña-Mondragón and Castillo 2013). Some people believed that if there were no predators, they would be in a better situation. Two workshops were conducted in the town of General Zaragoza and one in a rural settlement in Aramberri (average attendance was 20 people in each meeting) and apart from presenting the research results, the aim was to design solutions with the rural people to mitigate damages. Local people proposed that government should pay for the total losses they experienced and not only a percentage (as happens in some cases); they asked for free expert advice on how to minimize attacks on livestock and for economic support in order to build corrals for their animals. A workshop was also held in 2012 in Monterrey, the capital city of the state of Nuevo León with authorities from the environmental, agricultural, and rural development sectors. It was found that some of the participants did not know that there were jaguars present in the state. Listening to the results on economic losses, they agreed that it was an important issue to attend to. In 2013, financial support was obtained to buy and locate phototrapping cameras and 20 of these were placed on a privately owned ranch, whose family had been farmers but now own approximately 6000 hectares in a mountainous region where predators are found. The proprietor agreed to lend his land for the study and through the years
(2013-2015) more cameras were added to his ranch and in three surrounding ejidos (a tenure system in Mexico that combines private and communal lands where most rural producers in Mexico live; Morett-Sánchez and Cossío-Ruiz 2017). This was part of a community monitoring program that was an essential part of the project. An average of 15 cameras per year were placed at different sites (some were lost or broken) and around 128 thousand photos were obtained.

Fig. 3. Location of the study site in Nuevo León state, Mexico showing the two municipalities in which the work has been conducted.

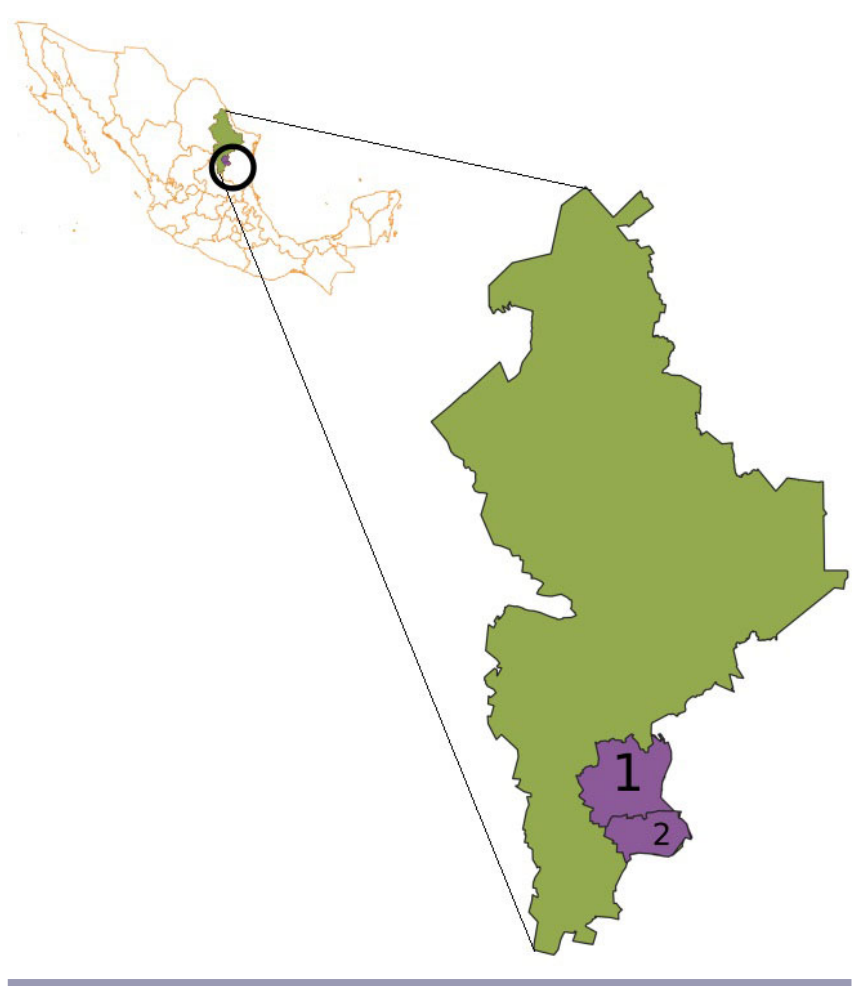

Local people were trained to manage the cameras; they operated them, georeferenced the sites, changed memory sticks, and decided where to place them. All the participants where paid for their work and youths were provided with tablets and laptops in order to process the data collected. They created a database that included global positioning information. After a year, the computing equipment was given as a gift to all the participants in return for their service. Some of the findings include the identification of middle-sized mammals, the use of habitat by different species, and the activity patterns of jaguar, cougars, and their prey, but it was also possible to see unsupervised livestock moving through forests, increasing the risk of being killed by wild animals (González-González 2017, Chávez-Espino 2019, Guijosa-Guadarrama 2019). Through an interpretative social research approach we documented people's perceptions about the problem and their ideas regarding how to mitigate the damage done by carnivores. With the information generated, approximately 700 leaflets were written and illustrated with black and white images and were distributed in 40 communities. A public activity held in General Zaragoza called "The Tiger 
Festival" (people call jaguars tigers) was organized in 2014 where 80 adults and 110 children attended. Games were prepared and short talks given on the biological aspects of jaguars and their ecological relevance. Information was also offered about the government's economic compensation when a wild animal kills livestock. An arts and crafts competition was organized for women interested in creating crafts with big animal motifs (information about how to participate was provided before the festival). Six fine crafts were submitted and three were awarded. Women received as prizes boxes with food, which they happily received. They expressed they felt proud because their work was recognized. All of these activities (Fig. 4) not only helped in the continuity of the research project, but contributed to the building of strong relationships with the local families. In 2015, the research aim continued to be on how people manage their livestock. It was found that certain practices favor predation such as letting the livestock move through forested areas and stay near rivers; having proper control of their herds not only reduces the possibility of killings, but also reduced the conflict between humans and carnivores. Similar results were found in a study conducted at the same time in southeast Mexico (PeñaMondragón et al. 2017). Based on results from the two sites, a simple logbook was designed to keep records of animals (using black and white drawings instead of words) as well as a manual explaining actions that people can take to mitigate predation of their animals. They were both printed using governmental funds. In the southeast of Mexico 250 copies were distributed in six communities and the work is now being monitored. Funds are expected to be obtained in order to distribute similar materials in Nuevo León. It should be stressed however, that after the continuous interactions, as well as communication interventions, people have contacted the research team for advice when they have problems caused by predators. They even preserved the remains of a predator for the researchers to use (this shows the acknowledgement they have and an understanding that the goal is to prevent the big animals from disappearing or become extinct). We have been able to confirm that some small actions to better manage livestock have been taken by some families. The experience has shown that in order to mitigate and help solve the conflict between big predators and rural people, the social component needs to be in the foreground, considering at all times the ecological conditions. It can also be said that the socialecological approach to research requires close communication with rural communities, as well as organizing activities where children, young people, and families can participate in projects. The decreasing number of attacks on livestock by carnivores and the hunting of carnivores by humans illustrate the success of this approach

\section{CONCLUSION}

In academic communities, scientists from different disciplines have been working on environmental problems for more than 50 years. Forming multidisciplinary teams, some are moving toward interdisciplinary approaches and others are working in transdisciplinary projects, all in an effort to respond to the urgent and distressing environmental crisis. Among the many themes in this field we can mention issues relating to environmental justice that are of great relevance in the urgent need to construct sustainable societies.
Fig. 4. Photos of the case study work. (A) presentation of the project to the Livestock Associations; (B) and (C) collection of data with local people (survey); (D) presenting the results to the Livestock Associations; (E) inviting people to participate in workshops aimed at finding solutions; $(F)$ participants of a workshop in an ejido; $(\mathrm{G})$ participants presenting proposals to mitigate the conflict; $(\mathrm{H})$ workshop with governmental authorities in the capital city of Nuevo León; (I) planning with local people the biological monitoring of medium and large mammals; (J) installation of phototrapping cameras; (K) first images collected; (L) activities with children; and (M) woman who won the crafts contest at the Tiger Festival.

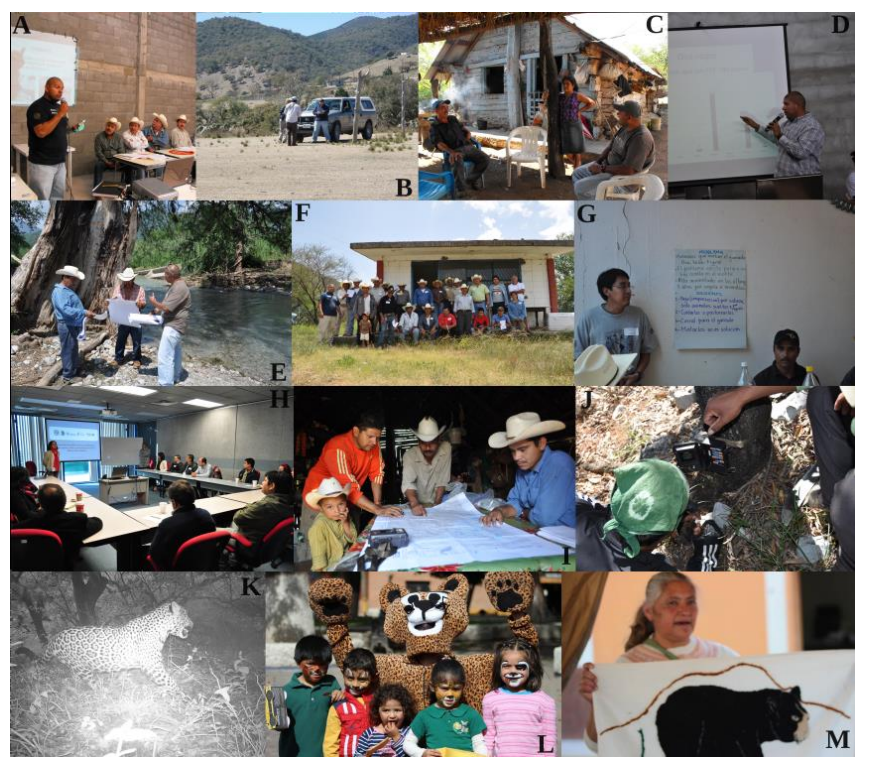

SES science is a broad and important umbrella under which social science involvement can occur in a variety of ways. Basic understanding by biophysical sciences and the diverse approaches of the social sciences are much needed if there is interest and commitment in the long-term maintenance of social-ecological systems from local to global scales. In the case above, the better the social and the ecological dimensions are thought through and are articulated in the project, the better the results obtained. SES scientists also need to become more active in the design, planning, and implementation of strategies that link their scientific findings to their use in conservation, restoration, territorial planning, as well as in the formulation and implementation of policies or other practices that support the transit toward sustainability. This is not an easy task, particularly because the biophysical sciences and the social sciences have been considered antagonistic and methodologically irreconcilable. However, moving social sciences to the center instead of maintaining the biophysical disciplines in the center can improve articulation among multi-, inter-, and transdisciplinary teams and projects. In the end, human decision are responsible for the environmental crisis, and as the case study above illustrates, people's participation in research projects provides valuable information that is necessary for local solutions and policy design. 
Responses to this article can be read online at: http://www.ecologyandsociety.org/issues/responses. php/11345

\section{Acknowledgments:}

This paper is part of a project about the social appropriation of social-ecological knowledge in Mexico, which received funding from Proyectos de Investigación e Innovación Tecnológica of the Universidad Nacional Autónoma de México (PAPIIT IN301817). We are very grateful to the anonymous reviewers that made suggestions and very relevant observations that improved our manuscript. We also thank Carlos Villaseñor for making the figures, Karla Tapia for her help with the references, and Sarah Bologna for the English editing.

\section{LITERATURE CITED}

Adams, W. M. 2007. Thinking like a human: social science and the two cultures problem. Oryx 41:275-276. https://doi. org/10.1017/S0030605307004131

Adorno, T., H. Albert, T. Dahrendorf, J. Habermas, H. Pilot, and K. Popper. 1976. The positivist dispute in German sociology. Heinemann, London, UK.

Anderson, G. L, and M. Montero-Sieburth. 1998. Educational qualitative research in Latin America: the struggle for a new paradigm. Routledge, New York, New York, USA. https://doi. org/10.4324/9781315048468

Balvanera, P., T. M. Daw, T. Gardner, B. Martín-López, A. Norström, C. Ifejika Speranza, M. Spierenburg, E. M. Bennett, M. Farfan, M. Hamann, J. N. Kittinger, T. Luthe, M. Maass, G. D. Peterson, and G. Pérez-Verdin. 2017. Key features for more successful place-based sustainability research on social-ecological systems: a Programme on Ecosystem Change and Society (PECS) perspective. Ecology and Society 22(1):14. https://doi. org/10.5751/ES-08826-220114

Beal, G. M., W. Dissanayake, and S. Konoshima. 1986. Knowledge generation, exchange, and utilization. Westview, Boulder, Colorado, USA.

Begon, M., J. L. Harper, and C. R. Townsend. 1986. Ecology: individuals, populations and communities. Sinaver Associates Inc, Sunderland, Massachusetts, USA.

Berger, P. L., and T. Luckmann. 1991. The social construction of reality. Penguin Books, London, UK.

Berkes, F., J. Colding, and C. Folke, editors. 2003. Navigating social-ecological systems: building resilience for complexity and change. Cambridge University Press, Cambridge, UK. https://doi. org/10.1017/CBO9780511541957

Berkes, F., C. Folke, and J. Colding, editors. 1998. Linking social and ecological systems: management practices and social mechanisms for building resilience. Cambridge University Press, Cambridge, UK.
Brondizio, E. S., K. O'Brien, X. Bai, F. Biermann, W. Steffen, F. Berkhout, C. Cudennec, M. C. Lemos, A. Wolfe, J. PalmaOliveira, and C. T. A. Chen. 2016. Re-conceptualizing the Anthropocene: a call for collaboration. Global Environmental Change 39:318-327. https://doi.org/10.1016/j.gloenvcha.2016.02.006

Cantrell, D. C. 1993. Alternative paradigms in environmental education research: the interpretive perspective. Pages 81-105 in R. Mrazek, editor. Alternative paradigms in environmental education research. North American Association for Environmental Education, Troy, Ohio, USA.

Castillo, A., A. Torres, A. Velázquez, and G. Bocco. 2005. The use of ecological science by rural producers: a case study in Mexico. Ecological Applications 15:745-756. https://doi. org/10.1890/03-5360

Castillo, A., J. H. Vega-Rivera, M. Pérez-Escobedo, G. RomoDíaz, G. López-Carapia, and B. Ayala-Orozco. 2018. Linking social-ecological knowledge with rural communities in Mexico: lessons and challenges towards sustainability. Ecosphere 9(10): e02470. https://doi.org/10.1002/ecs2.2470

Chávez-Espino, E. 2019. Patrones de actividad del Oso Negro en el Sur de Nuevo León, México. Tesis licenciatura, Universidad Michoacana de San Nicolas de Hidalgo, México.

Clements, D. 1998. The historical foundations of ethnobiology. Journal of Ethnobiology 18(2):161-187.

Collins, S. L., S. R. Carpenter, S. M. Swinton, D. E. Orenstein, D. L. Childers, T. L. Gragson, N. B. Grimm, J. M. Grove, S. L. Harlan, J. P. Kaye, et al. 2011. An integrated conceptual framework for long-term social-ecological research. Frontiers in Ecology and the Environment 9(6):351-357. https://doi. org/10.1890/100068

De la Garza, E. 2012. La metodología marxista y el configuracionismo en América Latina. Pages 236-266 in E. De la Garza and G. Leyva, editors. Tratado de metodología de las ciencias sociales: perspectivas actuales. Fondo de Cultura Económica, Universidad Autónoma Metropolitana, Unidad Iztapalapa, México D.F., México.

Denzin, N. K., and Y. S. Lincoln, editors. 2000. Handbook of qualitative research. SAGE, Thousand Oaks, California, USA.

Drury, R., K. Homewood, and S. Randall. 2011. Less is more: the potential of qualitative approaches in conservation research. Animal Conservation 14:18-24. https://doi.org/10.1111/ j.1469-1795.2010.00375.x

Durkheim, E. 2001. Las reglas del método sociológico. Fondo de Cultura Económica, México D.F, México.

Endter-Wada, J., D. Blahna, R. Krannich, and M. Brunson. 1998. A framework for understanding social science contributions to ecosystem management. Ecological Applications 8:891-904. https://doi.org/10.1890/1051-0761(1998)008[0891:AFFUSS]2.0.CO;2

Ehrlich, P. R. 1989. Discussion: ecology and resource management: is ecological theory any good in practice? Pages 306-318 in J. Roughgarden, R. M. May, and S. A. Levin, editors. Perspectives in ecological theory. Princeton University Press, Princeton, New Jersey, USA. https://doi.org/10.1515/9781400860180.306 
Ehrlich, P. R. 1997. A world of wounds: ecologists and the human dilemma. Ecology Institute, Luhe, Germany.

Fontana, A., and J. H. Frey. 2000. The interview: from structured questions to negotiated text. Pages 645-672 in N. K. Denzin and Y. S. Lincoln, editors. Handbook of qualitative research. SAGE, Thousand Oaks, California, USA.

Fox, H. E., C. Christian, J. C. Nordby, O. R. W. Pergams, G. D. Peterson, and C. R. Pyke. 2006. Perceived barriers to integrating social science and conservation. Conservation Biology 20 (6):1817-1820. https://doi.org/10.1111/j.1523-1739.2006.00598.x

Freire, 1998. ¿Comunicación y extensión? Siglo XXI Editores, México D.F, México.

Funtowicz, S. O., and J. R. Ravetz. 1993. Science for the postnormal age. Futures 25(7):739-755. https://doi.org/10.1016/0016-3287 (93)90022-L

Funtowicz, S., and J. Ravetz. 2003. Post-normal science. Internet encyclopaedia of ecological economics. International Society of Ecological Economics, London, UK.

García, R. 2006. Epistemología y teoría del conocimiento. Salud Colectiva 2:(2)109-122. https://doi.org/10.18294/sc.2006.60

García, R. 2011. Interdisciplinariedad y sistemas complejos. Revista Latinoamericana de Metodología de las Ciencias Sociales 1(1):66-101.

Geertz, C. 1973. The interpretation of culture. Basic Books, New York, New York, USA.

Gibbons, M., C. Limoges, H. Nowotny, S. Schwartzman, P. Scott, and M. Trow. 1994. Thenew production of knowledge: the dynamics of science and research in contemporary societies. SAGE, Thousand Oaks, California, USA.

González-González, S. P. 2017. Hábitos alimentarios del gato montés (Lynx rufus) en el sur de Nuevo León y su relación con la ganadería. Tesis licenciatura. Universidad Nacional Autónoma de México, México

Guijosa-Guadarrama, E. 2019. Interacciones espacio-temporales del puma con sus presas potenciales silvestres y domésticas en el sur de Nuevo León, México. Tesis licenciatura. Universidad Nacional Autónoma de México, México

Haberl, H., V. Winiwarter, K. Andersson, R. U. Ayres, C. Boone, A. Castillo, G. Cunfer, M. Fischer-Kowalski, W. R. Freudenburg, E. Furman, R. Kaufmann, F. Krausmann, E. Langthaler, H. Lotze-Campen, M. Mirtl, C. L. Redman, A. Reenberg, A. Wardell, B. Warr, and H. Zechmeister. 2006. From LTER to LTSER: conceptualizing the socioeconomic dimension of longterm socioecological research. Ecology and Society 11(2):13. https://doi.org/10.5751/ES-01786-110213

Hernández, L. 2010. Antes de empezar con metodologías participativas. Observatorio nacional de ciudadanía y medio ambiente sostenible. Cuadernos CIMAS, Madrid, España.

Horkheimer, M. 2003. Teoría Crítica. Amorrortu Editores, Buenos Aires, Argentina.

Janesick, V. J. 2000. The choreography of qualitative research design: minuets, improvisations and crystallization. Pages
379-399 in N. K. Denzin and Y. S. Lincoln, editors. Handbook of qualitative research. SAGE, Thousand Oaks, California, USA.

Jardel, E. J., M. Maass, and V. Rivera-Monroy, editors. 2011. La investigación ecológica de largo plazo en México. Editorial Universitaria-Universidad de Guadalajara, Guadalajara, México.

Jones, P. C., and J. Q. Merritt. 1999. Critical thinking and interdisciplinarity in environmental higher education: the case for epistemological and values awareness. Journal of Geography in Higher Education 23:349-357. https://doi.org/10.1080/03098269985290

Kates, R. W. 2011. What kind of a science is sustainability science? Proceedings of the National Academy of Sciences 108 (49):19449-19450. https://doi.org/10.1073/pnas.1116097108

Kates, R. W., W. C. Clark, R. Corell, J. M. Hall, C. C. Jaeger, I. Lowe, J. J. McCarthy, H. J. Schellnhuber, B. Bolin, N. M. Dickson, S. Faucheux, G. C. Gallopin, A. Grübler, B. Huntley, J. Jäger, N. S. Jodha, R. E. Kasperson, A. Mabogunje, P. Matson, H. Mooney, B. Moore III, T. O'Riordan, and U. Svedin. 2001. Sustainability science. Science 292:641-642. https://doi.org/10.1126/science.1059386

Kuhn, T. 1970. The structure of scientific revolutions. The University of Chicago Press, Chicago, Illinois, USA.

Lang, D. J., A. Wiek, M. Bergmann, M. Stauffacher, P. Martens, P. Moll, M. Swilling, and C. J. Thomas. 2012. Transdisciplinary research in sustainability science: practice, principles, and challenges. Sustainability Science 7(1):25-43. https://doi. org/10.1007/s11625-011-0149-x

Lélé, S., and R. B. Norgaard. 2005. Practicing interdisciplinarity. Bioscience 55:967-975. https://doi.org/10.1641/0006-3568(2005) 055[0967:PI]2.0.CO;2

Lincoln, Y. S., and E. G. Guba. 2000. Paradigmatic controversies, contradictions, and emerging confluences. Pages 163-188 in N. K. Denzin and Y. S. Lincoln, editors. Handbook of qualitative research. SAGE, Thousand Oaks, California, USA.

Lubchenco, J., A. M. Olson, L. B. Brubaker, S. R. Carpenter, M. M. Holland, S. P. Hubbell, S. A. Levin, J. A. MacMahon, P. A. Matson, J. M. Melillo, et al. 1991. The sustainable biosphere initiative: an ecological research agenda: a report from the Ecological Society of America. Ecology 72:371-412. https://doi. org/10.2307/2937183

MacMynowsky, D. P. 2007. Pausing at the brink of interdisciplinarity: power and knowledge at the meeting of social and biophysical science. Ecology and Society 12(1):20. https://doi. org/10.5751/ES-02009-120120

Morett-Sánchez, J. C., and C. Cosío-Ruiz. 2017. Panorama de los ejidos y comunidades agrarias en México. Agricultura, Sociedad y Desarrollo 14:125-152.

Naiman, R. J. 1999. A perspective in interdisciplinary science. Ecosystems 2:292-295. https://doi.org/10.1007/s100219900078

Newing, H. 2011. Conducting research in conservation: social science methods and practice. Routledge, New York, New York, USA. https://doi.org/10.4324/9780203846452

Nicolescu, B. 2012. The need for transdisciplinarity in higher education in a globalized world. Transdisciplinary Journal of Engineering \& Science 3:11-18. https://doi.org/10.22545/2012/00031 
Nissani, M. 1997. Ten cheers for interdisciplinarity: the case for interdisciplinary knowledge and research. Social Science Journal 34:201-216. https://doi.org/10.1016/S0362-3319(97)90051-3

O'Brien, J., and P. Kollock. 2001. What is real? Pages 3-14 in J. O'Brien and P. Kallock, editors. The production of reality. Essays and readings on social interaction. SAGE, Thousand Oaks, California, USA.

O'Neil, R. V. 2001. Is it time to bury the ecosystem concept? (With full and military honors, of course!). Ecology 82:3275-3284. https://doi.org/10.1890/0012-9658(2001)082[3275:iittbt]2.0.co;2

Ostrom, E. 2009. A general framework for analyzing sustainability of social-ecological systems. Science 325:419-422. https://doi.org/10.1126/science.1172133

Patton, M. Q. 2002. Qualitative interviewing. Pages 339-428 in M. Q. Patton, editor. Qualitative research and evaluation methods. SAGE, Thousand Oaks, CA, USA.

Peña-Mondragón, J. L., and A. Castillo. 2013. Depredación de ganado por jaguar y otros carnívoros en el noreste de México. Therya 4:431-46. https://doi.org/10.12933/therya-13-153

Peña-Mondragón, J. L., A. Castillo, A. Hoogesteijn, and E. Martínez-Meyer. 2017. Livestock predation by jaguars Panthera onca in south-eastern Mexico: the role of local peoples' practices. Oryx 51(2):254-262. https://doi.org/10.1017/S0030605315001088

Pickett, S. T. A., W. R. Burch Jr, and J. M. Grove. 1999. Interdisciplinary research: maintaining the constructive impulse in a culture of criticism. Ecosystems 2(4):302-307. https://doi. org/10.1007/s100219900081

Redman, C. L., J. M. Groove, and L. H. Kuby. 2004. Integrating social science into the long-term ecological research (LTER) network: social dimensions of ecological change and ecological dimensions of social change. Ecosystems 7:161-171. https://doi. org/10.1007/s10021-003-0215-Z

Retamozo, M. 2012. Constructivismo: Epistemología y Metodología en las ciencias sociales. Pages 325-351 in E. De la Garza and G. Leyva, editors. Tratado de metodología de las ciencias sociales: perspectivas actuales. Fondo de Cultura Económica, Universidad Autónoma Metropolitana, Unidad Iztapalapa: México D.F., México.

Robottom, I., and P. Hart. 1993. Research in environmental education: engaging the debate. Deakin University, Geelong, Victoria, Australia.

Schoenberger, E. 2001. Interdisciplinarity and social power. Progress in Human Geography 25:365-382. https://doi. org/10.1191/030913201680191727

Schuttenberg, H. Z., and H. K. Guth. 2015. Seeking our shared wisdom: a framework for understanding knowledge coproduction and coproductive capacities. Ecology and Society 20(1):15. https:// doi.org/10.5751/ES-07038-200115

Spalding, A. K., K. Biedenweg, A. Hettinger, and M. P. Nelson. 2017. Demystifying the human dimension of ecological research. Frontiers in Ecology and the Environment 15:119-119. https://doi. $\underline{\mathrm{org} / 10.1002 / \text { fee. } 1476}$
Spangenberg, J. H. 2011. Sustainability science: a review, an analysis and some empirical lessons. Environmental Conservation 38:275-287. https://doi.org/10.1017/S0376892911000270

Strauss, A. L. 1995. Qualitative analysis for social scientists. Cambridge University Press, Cambridge, UK. https://doi. org/10.1017/CBO9780511557842

Taagepera, R. 2008. Making social sciences more scientific: the need for predictive models. Oxford University Press, New York, New York, USA.

Tarrés, M., editor. 2008. Observar, escuchar y comprender. Sobre la tradición cualitativa en la investigación social. Miguel Ángel Porrúa, El Colegio de México y la Facultad Latinoamericana de Ciencias Sociales. México D.F., México.

van Dijk, T. 2016. Discurso y conocimiento: una aproximación sociocognitiva. Editorial Gedisa, Barcelona, España.

von Bertalanffy, L. 1969. General system theory: foundations, development, applications. George Brazille, New York, New York, USA.

Walters, C. J. 1998. Improving links between ecosystem scientists and managers. Pages 272-286 in M. L. Pace and P. M. Groffmann, editors. Successes, limitations, and frontiers in ecosystem science. Springer, Millbrook, New York, USA. https://doi. org/10.1007/978-1-4612-1724-4_11

Waltner-Toews, D., J. J. Kay, C. Neudoerffer, and T. Gitau. 2003. Perspective changes everything: managing ecosystems from the inside out. Frontiers in Ecology and the Environment 1:23-30. https://doi.org/10.1890/1540-9295(2003)001[0023:PCEMEF]2.0. $\mathrm{CO} ; 2$

Wear, D. N. 1999. Challenges to interdisciplinary discourse. Ecosystems 2:299-301. https://doi.org/10.1007/s100219900080

Wehrens, R. 2014. Beyond two communities: from research utilization and knowledge translation to co-production. Public Health 128:545-551. https://doi.org/10.1016/j.puhe.2014.02.004

Westley, F., S. R. Carpenter, W. A. Brock, C. S. Holling, and L. H. Gunderson. 2002. Why systems of people and nature are not just social and ecological systems. Pages 103-120 in L. H. Gunderson and C. S. Holling, editors. Panarchy: understanding transformations in human and natural systems. Island, Washington, D.C., USA.

Yin, R. K. 2016. Qualitative research from start to finish. Guildford, New York, New York, USA. 